\title{
Reply to the letter to the editor: "What are
} the effects of diagnostic imaging on clinical outcomes in patients with low back pain presenting for chiropractic care? A matched observational study." Jenkins et al., Chiropractic \& Manual Therapies 2021;29:46

\author{
Hazel J. Jenkins ${ }^{1 *}\left(\mathbb{D}\right.$, Alice Kongsted ${ }^{2}$, Simon D. French ${ }^{4}$, Tue Secher Jensen ${ }^{2,3,5}$, Klaus Doktor $^{2,3}$, \\ Jan Hartvigsen ${ }^{2,3}$ and Mark Hancock ${ }^{4}$
}

Reply to the letter to the editor

We thank Dr Lopes for his interest in our study [1] and his recognition of its importance.

We agree that our study did not specifically describe treatment or how the imaging performed may (or may not) have influenced treatment. As we stated in the original article, our aim was to determine whether treatment outcomes (e.g. pain intensity, disability) changed when the chiropractor decided to use imaging as part of patient management, not to explore how imaging may affect the specific treatment provided by chiropractors.

The primary purpose of imaging, as recommended by clinical practice guidelines, is to rule out serious pathology [2]. In our study, the mean number of patients referred for imaging was $24 \%$ and up to $64 \%$ of patients were referred for imaging depending on the individual chiropractor. Therefore, it is likely that imaging was not being performed to rule out serious pathology alone, which occurs in less than $1 \%$ of low back pain presentations [3]. Rather, some chiropractors may have been

\footnotetext{
*Correspondence: hazel.jenkins@mq.edu.au

${ }^{1}$ Faculty of Medicine, Health and Human Sciences, Macquarie University, Room 2232, Level 2, 75 Talavera Rd, Sydney 2109, Australia
}

Full list of author information is available at the end of the article referring for imaging when they thought it likely to change or inform patient management.

In our study we attempted to approximate randomisation by matching patients on known baseline data, including intention to use spinal manipulation. By doing this we attempted to make the matched groups as similar as possible so that the chiropractor's decision to refer, or not refer, for imaging would be the key difference between the groups. We also controlled for the chiropractor in the analysis to account for possible differences between individual chiropractors. As described in the limitations section of our article, we could not account for unmeasured variables; however, we considered that key variables likely to affect the decision to refer for imaging were accounted for.

For these reasons we believe that our conclusion that the decision to refer for imaging did not result in better clinical outcomes is appropriate. A randomised controlled trial is indicated to further explore this area without the limitations inherent in a matched observational design.

We also agree with Dr Lopes that future studies to describe how imaging informs treatment and whether different types of imaging assessment change clinical original author(s) and the source, provide a link to the Creative Commons licence, and indicate if changes were made. The images or other third party material in this article are included in the article's Creative Commons licence, unless indicated otherwise in a credit line to the material. If material is not included in the article's Creative Commons licence and your intended use is not permitted by statutory regulation or exceeds the permitted use, you will need to obtain permission directly from the copyright holder. To view a copy of this licence, visit http://creativecommons.org/licenses/by/4.0/. The Creative Commons Public Domain Dedication waiver (http://creativecommons.org/publicdomain/zero/1.0/) applies to the data made available in this article, unless otherwise stated in a credit line to the data. 
outcomes are needed. We will note though that in the treatment of low back pain, there is currently no evidence that spinal manipulation techniques that use imaging as part of the clinical decision making about where and how to perform the treatment produce superior results $[4,5]$.

\section{Acknowledgements}

Not applicable.

\section{Authors' contributions}

$\mathrm{HJ}$ drafted the letter. AK, SF, TSJ, KD, JH, and $\mathrm{MH}$ reviewed and approved the final version. All authors read and approved the final manuscript.

\section{Funding}

Not applicable.

\section{Availability of data and materials \\ Not applicable.}

\section{Declarations}

Ethics approval and consent to participate

Not applicable.

\section{Consent for publication}

Not applicable.

\section{Competing interests}

AK is an Associate Editor, and SDF is Co-Editor-in-Chief, of Chiropractic \& Manual Therapies. The editorial management system automatically blinded them both from the submitted letter, and neither had any part in the editorial process of this letter. The other authors declare that they have no competing interests.

\section{Author details}

${ }^{1}$ Faculty of Medicine, Health and Human Sciences, Macquarie University, Room 2232, Level 2, 75 Talavera Rd, Sydney 2109, Australia. ${ }^{2}$ Department of Sports Science and Clinical Biomechanics, University of Southern Denmark, Odense, Denmark. ${ }^{3}$ Chiropractic Knowledge Hub, Odense, Denmark. ${ }^{4}$ Faculty of Medicine, Health and Human Sciences, Macquarie University, Sydney, Australia. ${ }^{5}$ Silkeborg Regional Hospital, Silkeborg, Denmark.

Received: 13 February 2022 Accepted: 16 February 2022

Published online: 01 March 2022

\section{References}

1. Jenkins HJ, Kongsted A, French SD, Jensen TS, Doktor K, Hartvigsen J, Hancock M. What are the effects of diagnostic imaging on clinical outcomes in patients with low back pain presenting for chiropractic care: a matched observational study. Chiropract Manual Ther. 2021, 29.

2. Bussieres A, Taylor J, Peterson C. Diagnostic imaging practice guidelines for musculoskeletal complaints in adults_-an evidenced-based approach — part 3: spinal disorders. J Manipulative Physiol Ther. 2008:31:33-88.

3. Henschke N, Maher CG, Refshauge KM, Herbert RD, Cumming RG, Bleasel $J$, York J, Das A, McAuley JH. Prevalence of and screening for serious spinal pathology in patients presenting to primary care settings with acute low back pain. Arthritis Rheum. 2009;60:3072-80.

4. Corso M, Cancelliere C, Mior S, Kumar V, Smith A, Côté P. The clinical utility of routine spinal radiographs by chiropractors: a rapid review of the literature. Chiropract Manual Ther. 2020:28:33.

5. Jenkins HJ, Downie AS, Moore CS, French SD. Current evidence for spinal $X$-ray use in the chiropractic profession: a narrative review. Chiropract Manual Ther. 2018;26:48.

\section{Publisher's Note}

Springer Nature remains neutral with regard to jurisdictional claims in published maps and institutional affiliations.
Ready to submit your research? Choose BMC and benefit from:

- fast, convenient online submission

- thorough peer review by experienced researchers in your field

- rapid publication on acceptance

- support for research data, including large and complex data types

- gold Open Access which fosters wider collaboration and increased citations

- maximum visibility for your research: over 100M website views per year

At BMC, research is always in progress.

Learn more biomedcentral.com/submissions 